all the three cases he uses as examples the claim that accidental infection with hepatitis virus had occurred via a trivial skin lesion was rejected. In the first the case was lost because the interval between the injury and the onset of hepatitis was only 25 days. In the second this argument could not be used, but the claim was rejected because the referee was not satisfied that there was enough evidence that viruses, unlike spirochaetes or pyogenic bacteria, could infect through a trivial skin lesion. One would have thought that smallpox vaccination provided sufficient evidence, but even if this were regarded as inadequate there is the epidemic reported in 1885 by $\mathrm{A}$. Lürman ${ }^{2}$ in which 191 individuals developed an attack of hepatitis out of a group of 1,289 vaccinated with a given batch of serum. In the third example the victim was a surgeon who developed hepatitis several weeks after he had operated upon a patient recently recovered from this disease. Here the claim was refused because there was no clear evidence of a skin lesion having been sustained at the time of the operation.

It should be noted that in none of these examples was it suggested by the insurance companies involved that the claimant had not received the infection from a patient, but only that the route of infection was more probably oral than cutaneous and hence did not fall within the terms of the policy. To those familiar with the extraordinary infectivity of virus-contaminated blood and with the extreme variability of the incubation period whatever the route of infection these decisions might seem questionable.

\section{HUNTER'S MUSEUM}

The Hunterian Museum was opened in 1813, containing the thirteen thousand specimens collected by John Hunter-in itself an achievement that alone deserves commemoration. Hunter died in 1793, and in 1799 Parliament granted George III $£ 15,000$ to buy the famous collection which was entrusted to the Company of Surgeons. Further grants made it possible to build in 1813 on the south side of Lincoln's Inn Fields a building "suitable to the purposes and dignity" of the Royal College of Surgeons into which the Company of Surgeons had been translated. The various grants from the Government eventually added up to $£ 57,500$, which is little enough when account is taken of the influence of John Hunter and his work on surgery, and of the great significance to doctors in the Commonwealthand indeed the world-of the Royal College of Surgeons of England and its world-famed Hunterian Museum.

Sir Arthur Porritt, P.R.C.S., told the distinguished gathering that witnessed the opening last week of the fully restored museum that by 1941 Hunter's thirteen thousand specimens had grown to sixty-three thousand: nearly half of them were destroyed in the German air-raid of May 10, 1941, the same Saturday night that witnessed the destruction of the factories of Messrs. Eyre \& Spottiswoode, the then printers of the British
Medical Journal. Sir Arthur was modest in stating that the College over which he presides " is doing a national job." It is doing an international, and especially a Commonwealth, job; and with its older sister the Royal College of Physicians of London refuses to be content merely with a local habitation and a name. Sir Arthur acknowledged in his speech the generous gift of the Wolfson trustees which had made possible the rebuilding of the museum. The debt of medicine to private benefactors is enormous. But surely the time has come for the State, for Government, to give pound sterling for pound sterling that has come out of private pockets. The Royal Colleges are national institutions that are part of modern Britain's claim to contemporary fame. It is little short of a scandal that our distinguished surgeons should have to spend so much of their time and energy in devising ways and means of keeping their College solvent and intact. As Sir Victor Negus, chairman of the trustees of the Hunterian Collection, told us last week, this was also the 150th anniversary of the opening of the museum. By office the First Lord of the Treasury is a trustee and Mr. Harold Macmillan in this capacity was also the first Prime Minister in office to visit the College. We may hope this was a happy omen, and that he and that other classical scholar, Lord Hailsham, will soon find ways to expand the scientific activities of the College in the old-fashioned and highly practical way pointed out by our captains of industry.

\section{CLINICAL MEETING AT STOKE-ON-TRENT}

The Annual Clinical Meetings of the British Medical Association have now got firmly into their stride. The programme of the meeting at Stoke-on-Trent next October is published in the Supplement this week. As can be seen, attendance at the scientific meetings on the two days of the gathering will not blind the visitor with science, but will give him the sort of information which he should find useful in his practice, whether that is in the hospital or in the patient's home. Once again the local organization, whose chairman is $\mathrm{Mr}$. J. S. Ramage, have been successful in persuading some of the most eminent authorities in their particular subjects to speak at the meetings.

The well-balanced scientific programme is supported by a series of social events at which the hosts will be the North Staffordshire Division, the Lord Mayor and Corporation of the City of Stoke-on-Trent, and other private well-wishers.

Anyone wishing to attend the meeting should make early application for accommodation. A list of hotels is given in the programme, but it may also be possible to take advantage of the private hospitality offered by members of the North Staffordshire Division.

Correction.-In our annotation on Research on Fertility Control (May 18, p. 1303) the dosage of the new oral contraceptive tablet found effective in Dr. Eleanor Mears's trial was $4 \mathrm{mg}$. (not $2 \mathrm{mg}$.) of megestrol acetate and $0.05 \mathrm{mg}$. of ethinyloestradiol. 